\title{
GENDER DIFFERENTIAL IN LEAFY VEGETABLE PRODUCTION IN LAGELU LOCAL GOVERNMENT AREA OF OYO STATE, NIGERIA
}

\author{
Olanrewaju, K.O. ${ }^{1}$, Akintunde, O.K. ${ }^{2}$, Adeoye, I.B. ${ }^{3}$ and Bamiwuye, O.A. ${ }^{1}$ \\ ${ }^{1}$ Department of Agricultural Extension and Rural Development, Osun State University, \\ Osogbo, Nigeria \\ ${ }^{2}$ Department of Agricultural Economics and Agribusiness Management, Osun State \\ University, Osogbo, Nigeria \\ ${ }^{3}$ National Horticultural Research Institute, Ibadan, Oyo State
}

Correspondence Email: olaide.akintunde@ uniosun.edu.ng

\begin{abstract}
There exists gender imbalance in resource access and utilization in agricultural enterprises which predisposes women to frustration and marginalization. This study examined gender differences in leafy vegetable production in Lagelu Local Government Area of Oyo State, Nigeria.Primary data were collected from 120 male and female leafy vegetable farmers with the aid of structured questionnaire using multi-stage sampling technique. Descriptive and inferential statistics were used to analyze the data. The findings revealed that half $(50.0 \%)$ of the male farmers had post-primary school education while less than one-third (31.0\%) of the female farmers had post-primary school education.More than half $(65.4 \%)$ and52.4\% of the male and female farmers, respectively, had no contact with extension agents. More than half (66.7\%) and majority (73.8\%) of the male and female farmers, respectively financed their farm enterprise with their personal savings.It was found that labour utilization by male farmers differs significantly from the use of labour by female farmers ( $t=3.79, P \unlhd 0.001)$, while there was no significant difference in farm income among the male and female leafy vegetable farmers.It was concluded that leafy vegetable farmers differ in the modalities of their production on gender basis even though they acquire fairly the same income from the enterprise. This study recommends that the government should assist the farmers with credit of low interest rate and credit institution too should be encouraged to do so. Government should revitalize extension services and regular training of the farmers by the extension agents is crucial for farmers' productivity.
\end{abstract}

Keywords: Male, female, disparity, input, utilization

https://dx.doi.org/10.4314/jafs.v19i1.9

\section{INTRODUCTION}

Vegetables are sustainable and affordable dietary sources of micronutrients for maintenance of good health (Adeoye, 2020) and an important feature of Nigerian's diet (Busari et al., 2012). Vegetables are rich sources of many essential micronutrients, including vitamins $C$ and $\mathrm{K}$, folate, thiamine, carotenes, several minerals, and dietary fibre (Clay et al., 2005). Vegetable production can make a significant difference to smallholder farmers' income and can contribute to livelihood diversification and employment for farmers, especially during the 
Journal of Agriculture and Food Sciences

Volume 19 Number 1, April 2021 pp 120-133

Olanrewaju, K.O., Akintunde, O.K., Adeoye, I.B. and Bamiwuye, O.A. dry season (Obuobie et al. 2006). It is recognized that women and men throughout the world are engaged in a range of productive activities essentials to household welfare and economic growth (Busari et al. 2012). Gender refers to the socially assigned roles and behaviours of men and women (Joshi and Kalauni, 2018). According to Welch et al. (2000), different roles played by the men and women are due to gender disparity leading to bias in the distribution of resources, wealth, work and decision-making. Gender has become a fundamental issue and crucial in the transformation of subsistence agriculture to market-oriented farming (Befikadu, 2016). Despite the fact that a large proportion of agricultural activities is often dominated by men, it is worthy of note that women's contribution to subsistence farming is significant (Befikadu, 2016).

Women are more prone to be constrained in their access to inputs in growing crop, resulting in lower levels of fertilizer, labour, and other inputs than is optimal (Oseni et al. 2015). Obasi and Kanu (2014) found that male farmers had more access to hired labour than their female counterparts in food production while Ogunniyi et al. (2012) found that females used more hired labour and less family labour when compared to men in Ondo state in cocoa production. Additionally, Rufai et al. (2018) reported that more man-hours were utilized on malemanaged plots when compared to those managed by females and males had a higher level of labour productivity compared to females in their study on gender analysis of input utilization and agricultural labour productivity (Rufai et al. 2018). Gender differential in vegetableproducing and vegetable-trading households need to be understood to make value chain development equitable (Fischer et al. 2020). Analysis of gender equality does matter for overall economic development and welfare measurement (Ajayi, 1997). Despite this importance, several studies on vegetable production system such as Olusola, (2015), Baruwa and Adesina (2013), Busari et al. (2012), Mbanasor and Kalu (2008), Omotesho et al. (2015), Isitor et al. (2016) and Ayanwale et al. (2011) have focused largely on the economics of production of vegetables and the marketing without the exploration of gender-based differences that might exist in the modalities of leafy vegetable production. As such, there is an information gap on the influence of gender on production activities, labour utilization and income of vegetable farmers and hence this study. The broad objective was to disaggregate on gender basis the leafy vegetable production system in Lagelu Local Government Area of Oyo State, Nigeria. Specific objectives of the study were to:

i. investigate the production activities of male and female leafy vegetable farmers in the study area; 
Journal of Agriculture and Food Sciences

Volume 19 Number 1, April 2021 pp 120-133

Olanrewaju, K.O., Akintunde, O.K., Adeoye, ii. examine the gender differential in labour utilization of leafy vegetable production; and iii. determine the existence of income disparity among male and female leafy vegetable farmers.

\section{Hypotheses of the study}

In view of the above specific objectives, two hypotheses were set in the null form as follows:

$\mathrm{Ho}_{1}$ : There is no significant difference in the labour utilization of male and female leafy vegetable farmers; and

$\mathrm{Ho}_{2}$ : There is no significant difference in the farm income of male and female leafy vegetable farmers.

\section{MATERIALS AND METHOD}

The study was carried out in Lagelu Local Government Area of Oyo state. Its headquarters is Iyana-Offa at the Eastern part of Ibadan, the capital of Oyo State. It shares boundary with Iwo Local Government in the North and Egbeda Local Government in the west. It is also bounded in the south by Ibadan North East Local Government and Akinyele Local Government. Lagelu Local Government covers a total area of 416 square kilometres and consists of 14 political wards of over 80 towns and 567 villages while $55 \%$ of these settlements are rural in nature with a total population of 147,957 (NPC, 2006). It consists of multi-ethnic groups of people dominated by the Yorubas. Others include Urhobos, Itsekiris, Igbos, Hausa-Fulanis and foreigners from other parts of the world. The rainfall pattern and humidity of the Local Government area include wetland, plain, highland and periodic rainfall as it applies in other parts of the Southwestern, Nigeria. The climate of the area favours the cultivation of crops like maize, yam, cassava, millet, rice, plantain, cacao tree, palm tree, cashew and leafy vegetable.

\section{Source and type of data}

Primary data were used for this study. The primary data were obtained with the aid of a structured questionnaire and unstructured interview. The questionnaire were structured to capture data on socio-economic variables, inputs utilization, credit accessibility, mode of land ownership, and income accrued in the vegetable production. 
A multistage sampling technique was employed in selecting the leafy vegetable farmers in the study area. The first stage was random selection of six wards out of the fourteen wards in the Local Government Area. The second stage was the purposive selection of two villages known for leafy vegetable farming from each ward based on the available information from ADP zonal office. The last stage involved random selection of ten leafy vegetable farmers from each of the villages selected in stage two. This gave a sample size of one hundred and twenty (120) leafy vegetable farmers used for study.

\section{Analytical techniques and models}

The study employed analytical tools based on the stated objectives. They include descriptive and inferential statistics. The descriptive statistics tools used were mean, standard deviation and percentages which were applied to describe socio-economic characteristics of the vegetable farmers and their production activities. For inferential statistics, T-tests were carried out to examine the effects of gender on the farmers' labour utilization and income from leafy vegetable production.

\section{RESULTS AND DISCUSSIONS}

\section{Socio-economic characteristics of the vegetable farmers}

Table 1 presents socio-economic characteristics of the leafy vegetable farmers. Results in Table 1 show that one third (33.3\%), 35.9\% and 30.8\% of the male vegetable farmers were below the age of 30 years, between 35-45 years and above 45 years, respectively, while majority (78.6\%) of the females were aged between 30-45 years. About one fifth $(21.4 \%)$ of the female leafy vegetable farmers were below 30 years in age and only $7.1 \%$ were found to be above 45years. This result shows that most of the female vegetable farmers were in the early middle ages of between 30-45 years, while the male vegetable farmers were more or less equally represented among the young and middle-aged farmers. Overall, the highest proportion of the leafy vegetable farmers was within the age range of 30-45 years. This disagrees with the findings of Busari et al. (2012) that vegetable farmers are mostly between 41 and 50 years of age.

More so, the results in Table 1 reveal that more female vegetable farmers $(28.6 \%)$ than the males (19.2\%) had no formal education, while $30.8 \%$ and $40.5 \%$ of the male and female 

vegetable farmers, respectively, had primary school education. About one third $(32.1 \%$ and $31 \%$ ) of male and female vegetable farmers, respectively had secondary school education just as $18.0 \%$ of the male vegetable farmers had tertiary education, while none of the female vegetable farmers had any tertiary education. These show that half $(50.1 \%)$ and only $31 \%$ of the male and female vegetable farmers, respectively had education above primary school level. This result implies that the male vegetable farmers had better access and opportunity to formal education in the area than the females. In other words, the females were more represented among the vegetable farmers with lower level of education than their male counterparts. This evidence indicates that the male and female be consistent were unequal in terms of exposure to formal education. This is not in conformity with findings of Olowa and Olowa, (2015). They reported that female vegetable farmers are more educated than their male counterpart.

Years of farming experience as presented in Table 1 shows that many (64.3\%) of the female vegetable farmers had farming experience of 10years and below while $23.8 \%$ and $11.9 \%$ of them had 11-20 years and 21-30years experience, respectively. As for the male leafy vegetable farmers, $43.6 \%$ and $42.3 \%$ had 0-10years and 11-20 years farming experience, respectively. More so, $11.5 \%$ and 2.6\% also had farming experience of between 21-30 years and above 30 years respectively. These show that while many of the female leafy vegetable farmers had not more than 10years experience in farming, more than half of the males had higher farming experiences above 10years. This indicates that the males were on the average more experienced in farming than their females. This may be attributable to earlier traditional socialization of males in farming than the females. However, this contradicts the findings of Olowa and Olowa, (2015) that females vegetable farmers have higher years of farming experience than males.

Also, the result in Table 1 reveals that more males in proportion (25.6\%) than females $(21.4 \%)$ acquired land for farming through inheritance, while more females in proportion $(52.4 \%)$ than males $(48.7 \%)$ rented land for vegetable production. More so, about one tenth $(9.5 \%)$ of female farmers bought the land used for farming while few $(2.6 \%)$ of males bought their land accordingly. About one fifth $(23.1 \%)$ and less than one fifth (16.7\%) of males and females, respectively accessed land through other unidentified sources. This means that higher proportion of the males had access to land through inheritance while more females had to purchase land for their leafy vegetable production. This reflects some level of inequality in male and female farmers access point to cultivable land for their production. This is in line 
Journal of Agriculture and Food Sciences

Volume 19 Number 1, April 2021 pp 120-133

Olanrewaju, K.O., Akintunde, O.K., Adeoye, with well-known views that there is gender inequality in accessibility to land for farming (Villarreal, 2013; Giroud and Huaman, 2019).

\section{Description of production activities of male and female vegetable farmers}

Table 2 presents the production activities of male and female vegetable farmers in the study area. The results show that about one-third of the male (34.6\%) and female (33.3\%) vegetable farmers preferred to grow Amaranthus while 38.5 percent of the males and 33.3 percent of the females were interested in the cultivation of Cochorus olitorius (jute leaf or Ewedu). About one fifth of male (19.2\%) and female (19.1\%) had preference for growing Solanum macrocarpon (garden egg leaf or Igbagba) and Celosiaargentea (Soko), respectively. The results indicate that the male and female farmers were more or less planting the same leafy vegetable types. This could be as a result of market demand of the vegetable types in the different parts of the study area which in turns determines what is planted by the farmers.

More than half $(64.1 \%)$ and $(66.7 \%)$ of both the male and female leafy vegetable farmers indicated that their personal experience was the source of knowledge utilized in their vegetable enterprise, respectively. On the other hand, those who learnt from their co-farmers constituted $20.5 \%$ and $23.8 \%$ of males and females, respectively. More so, a few (15.4\%) of the males learnt about vegetable production from extension agents. In view of these results, personal experience in vegetable production was depended on by majority of male and female leafy vegetable farmers for their production activities. Farmers experienced based knowledge has being widely acclaimed to have immense importance even in the technologically revolutionized agricultural systems (Sumane et al. 2017)

The result in Table 2 shows that the accessibility of the vegetable farmers to extension services. It was shown that many $(65.4 \%$ and $52.4 \%)$ of the male and female leafy vegetable farmers, respectively, did not have contact with agricultural extension agents. This high proportion of male and female leafy vegetable farmers who were not privileged to access extension services in the study area might be faced with information lag on innovation and modern techniques of vegetable production. However, there were more $(47.6 \%)$ females than males $(34.6 \%)$ that had contact with extension personnel. This result could be due to the common delineation of vegetables as women crops and as such extension service on vegetable production would be targeting the females more than the males. 

Personal savings was the major source of funding for vegetable production as shown in Table 2. Many $(66.7 \%$ and $73.8 \%)$ of the male and female farmers, respectively financed their farm enterprise with their personal savings. Implication of this finding is that there is financial limitation in production expansion by the vegetable farmers as majority of the farmers had no access to credit for rejuvenating their production cycles. This finding conforms with that of Agbo et al. 2015) which submitted that vegetable farmers do not have access to credits from formal institutions. Many (68\%) and one third (33.3\%) of the male and female leafy vegetable farmers, respectively consented that production decision making were made by men while half of the females (50.0\%) and only 6.4 percent of males attributed decision making to females. In addition, at least one quarter (25.6\%) of male respondents and 16.7 percent of the females opined enterprise decision-making was a joint one. On the average, decision making is mostly seen as a male task as indicated by most male respondents and a substantial number of female farmers. This reflects the domination of patriarchal traditions in agricultural production (Akanle et al. 2019; Onwutube, 2019).

\section{Labour utilization for leafy vegetable production activities}

Results in Table 3 show that majority of the male leafy vegetable farmers expended their personal energy for approximately $12(11.5 \pm 3.01)$ production activities and their spouses carried out approximately $4(4.38 \pm 4.12)$ activities. In the case of the female leafy vegetable farmers, about 9 activities $(9.26 \pm 4.02)$ were done by the women themselves, while their spouses assisted them with approximately 5 activities $(5.31 \pm 4.9)$. This connotes that each farmer devotes much time and energy to their farm while lesser efforts were expended by their spouses who are likely engaged in different business enterprise. To ascertain the statistical significance of the above gender utilization of personal and spouse's labour for carrying out the production activities, paired t -test result (Table 4) showed that the males' and females' utilization of personal labour differs significantly from their use of their spouses as labour ( $\mathrm{t}=10.23, \mathrm{P} \unlhd 0.001$ and $\mathrm{t}=3.06, \mathrm{P} \unlhd 0.05$, respectively).

More so, the female and male farmers delegated more activities to their male children (3.5 \pm 2.6 and 2.87 \pm 2.6$)$ than the female children (3.42 \pm 2.53 and $2.23 \pm 2.3$ ), respectively. However, the male farmers delegation of production activities to male children differs significantly from the extent at which they do so to female children ( $t=4.69, \mathrm{P} \unlhd 0.05)$, while in the case of the female farmers; activities delegated to male and female children did not differ significantly ( $\mathrm{t}=0.89 \mathrm{P} \unlhd 0.05$ ). This implies that a male leafy vegetable farmer in the study 
Journal of Agriculture and Food Sciences

Volume 19 Number 1, April 2021 pp 120-133
Olanrewaju, K.O., Akintunde, O.K., Adeoye, I.B. and Bamiwuye, O.A. area usually differentiate on gender basis the number of activities to be fuelled by their children labour, while the female farmers hardly do so significantly. It is expected that the male farmers will be more in control in delegating tedious farming activities to male children than female children as men are always in position of authority and control. As such, it is affirmed that there was a disparity in the labour rendered by the male children on their fathers' farm as contrary to their mothers' farm. The female farmers were also found to employ the service of hired labour for an average of 3 activities $(3.11 \pm 1.3)$ while the male farmers utilize labour for not more than 2 activities $(2.0 \pm 1.65)$.

Overall, the results show that the male farmers mostly fuelled their production activities with their personal energy and consequent lower level of utilization of hired and children labour than their female counterparts. This means that the male farmers bear the rigour of the production activities to a greater extent than the female farmers found to be exploring other sources of labour such as their family members and hired labour to a greater extent. In the same way, delegation of activities by both male and female leafy vegetable farmers to their children was more significantly skewed towards the male child than the female child. This means that the male child was more significantly involved in carrying out the production activities of their parents' leafy vegetable enterprise. These findings showcase gender disparity in the utilization of labour, a representation of gender roles differentiation in the performance of agricultural activities as exemplified in earlier studies like Food and Agriculture Organization FAO (2011), FAO and ECOWAS Commission (2018) and Onwutube (2019).

\section{Gender disparity in Leafy vegetable production income}

Evidence in Table 5 shows the gender disaggregated results of average income of leafy vegetable farmers per production cycle. It was shown that higher proportions $(46.2 \%$ and $35.7 \%$ ) of the male and female leafy vegetable farmers respectively obtained not more than $\$ 30,000$ per production cycle. Those who earned between $\$ 30,001$ and $\$ 40,000$ constituted $25.6 \%$ and $30.9 \%$ of the males and females, respectively, while only $10.3 \%$ and $16.7 \%$ earned above $\$ 50,0000$, respectively. The mean income per production cycle for the male leafy vegetable farmers was $\$ 45,076.92 \pm 8745.61$, while the females averagely obtained $\$ 39,880.95 \pm 5321.28$. These reveal that the income of majority of the male and female leafy vegetable farmers from each cycle of production is only about the national minimum wage of 
Journal of Agriculture and Food Sciences

Volume 19 Number 1, April 2021 pp 120-133
Olanrewaju, K.O., Akintunde, O.K., Adeoye, I.B. and Bamiwuye, O.A.

$\$ 30,000$ per month. Given this, the male and female leafy vegetable farmers are low-income earners.

\section{Results of hypotheses tests}

The results of independent t-test in Table 6show that there was significant gender difference in labour utilization in vegetable production. The utilization of labour by male farmers differs significantly from the use of labour by female farmers $(\mathrm{t}=3.79, \mathrm{P} \unlhd 0.05)$. On the contrary, there was no significant difference in accrued income per cycle of leafy vegetable production between the males and females ( $\mathrm{t}=0.38, \mathrm{P} \unlhd 0.05)$. These results implied that the gender differential in use of labour resource may not translate into income difference between male and female vegetable farmers. This could be an under-utilization of labour input or that labour has not been efficiently utilized to achieve higher level of productivity that will eventually impact positively on farm income.

\section{CONCLUSION}

This study affirms that most of the female vegetable farmers were in the early middle ages of between 30-45 years, while the male vegetable farmers were more or less equally represented among the young and middle-aged farmers. None of the female vegetable farmers had any tertiary education unlike the males. The experience in vegetable farming was slightly higher among males than the females. Higher proportion of the males had access to land through inheritance while females accessed their land mainly through renting. Many of the male and female leafy vegetable farmers had no contact with extension agents. Personal savings was the major source of financing the vegetable production. Tested hypotheses revealed that there was significant gender difference in labour utilization while there was contrary to income utilization. In essence, a gender differential in use of labour resource did not translate into income difference between male and female leafy vegetable farmers in the study area. In an attempt to increase the productivity and returns on investment for the vegetable farmers, it is recommended that the government should revitalize extension services and regular training of the farmers by the extension agents on optimal use of credit, labour, and other farm inputs which are crucial for optimal allocation of resources among the farmers for improved productivity and income. 
Agbo, F.U., Iroh, I.I., \& Ihemezie, E.J. (2015). Access to Credit by Vegetable Farmers in Nigeria: A Case Study of Owerri Agricultural Zone of Imo State, Nigeria. Asian Journal of Agricultural Research, 9, 155-165. DOI: 10.3923/ajar.2015.155.165. https://doi.org/10.3923/ajar.2015.155.165

Ajayi, S. (1997). Women in Agriculture as a Strategy for Food Security in Nigeria. Journal of Rural Development Administration, 29, 11-17.

Akanle, O., Ademuson, A. O., Adegoke, O. O., \& Okewumi, E. O. (2019). Gender and Marketing of Agricultural Produce in Nigeria. Gender and Behaviour, 17(2), 1284612858.

Ayanwale, A., Oyedele, D.J, Adebooye, O.C., \& Adeyemo, V.A. (2011). Socio-Economic Analysis of the Marketing Chain for Under-Utilised Indigenous Vegetables in Southwestern Nigeria, African Crop Science Society Conference, 10, 515-519.

Baruwa, O.I., \& Adesina, C.A. (2013). Economics of Leafy Vegetable Production, International Journal of vegetable science,19(1),21-25. https://doi.org/10.1080/19315260.2012.663069

Befikadu, K.F. (2016). The Role of Gender in Small Scale Irrigation Agriculture among Smallholder Farmers in Lume District in the Central Rift Valley of Ethiopia. A Thesis Submitted to the School of Natural Resources and Environmental Studies, Wondo Genet College of Forestry and Natural Resources Hawasa University Wondo Genet, Ethiopia In Partial Fulfillment of the Requirements for the Degree of Master of Science In Watershed Management.

Busari, A. O., Idris-Adeniyi, K.M., \& Oyekale, J.O. (2012). Economic Analysis of Vegetable Production by Rural Women in Iwo Zone of Osun State, Nigeria. Greener Journal of Agricultural Sciences: 3(1),006-011. https://doi.org/10.15580/GJAS.2013.1.110512231

Food and Agriculture Organization (FAO) and ECOWAS Commission (2018). National Gender Profile of Agriculture and Rural Livelihoods - Nigeria.Country Gender Assessment Series, Abuja. pp. 92.

Food and Agriculture Organization (FAO). (2011). The role of women in agriculture. The Food and Agriculture Organization of the United Nations. ESA Working Paper No. 1102

Fischer, G., Patt, N., Ochieng, J., \& Mvungi, H. (2020). Participation in and Gains from Traditional Vegetable Value Chains: a Gendered Analysis of Perceptions of Labour, Income and Expenditure in Producers' and Traders' Households. The European Journal of Development Research,3(2,)1080-1104. https://doi.org/10.1057/s41287-020-00257-0

Giroud, A., \& Huaman. (2019). Investment in agriculture and gender equality in developing countries. Transnational Corporations, 26(3),89-113. https://doi.org/10.18356/e7a807e6en

Isitor, S.U, Otunaiya, A.O., \& Iyanda, J.O. (2016). Efficiency of Vegetable Marketing in Peri-Urban Areas of Ogun State, Nigeria, Journal Of Agricultural Science, 8(3), 142150. https://doi.org/10.5539/jas.v8n3p142

Joshi, A., \& Kalauni, D. (2018). Gender Role in Vegetable Production in Rural Farming System of Kanchanpur, Nepal. SAARC J. Agri.,16(2),109-118. https://doi.org/10.3329/sja.v16i2.40263

Mbanasor, J.A., \& Kalu, K.C. (2008). Economic efficiency of commercial vegetable production system in Akwalbom state, Nigeria: A translog stochastic frontier cost function approach. Tropical and Subtropical Agroecosystems, 8(3),313-318 Universidad Autónoma de Yucatán Mérida, Yucatán, México.

National Population Commission (NPC). 2006. Analysis of Nigerian 2006 Census Results. 
Journal of Agriculture and Food Sciences

Volume 19 Number 1, April 2021 pp 120-133
Olanrewaju, K.O., Akintunde, O.K., Adeoye, I.B. and Bamiwuye, O.A.

Obasi, O. O., \& Kanu, W. N. (2014). Gender Access to Farm Labour and Coping Strategies: Implication for Food Productivity in Imo State, Nigeria. International Journal of Development and Sustainability, 3(8), 1777-1781.

Obuobie, E., Keraita, B., Danso, G., Amoah, P., Cofie, O. O., Raschid-Sally, L., \& Drechsel, P., et al. (2006).Irrigated Urban Vegetable Production in Ghana: Characteristics and Risks.IWMI-RUAF-CPWF, Accra, Ghana.

Odame, H. H., Hafkin, N. Wesseler, G., \& Boto, I. (2002). Gender and Agriculture in the Information Society. International Service for National Agricultural Research Briefing Paper No.55. The Hague, the Netherlands: ISNAR.

Ogunniyi, L. T., Ajao, O. A., \& Adeleke, O. A. (2012).Gender Comparison in Production and Productivity of Cocoa Farmers in Ile Oluji Local Government Area of Ondo State, Nigeria. Global Journal of Science Frontier Research Agriculture Biology, 12(5), 5963.

Olowa, O.A., \& Olowa, O.W. (2015).Gender Issues of Labour Participation in Vegetable Production in Ikorodu Local Government Area of Lagos State, Nigeria.Current

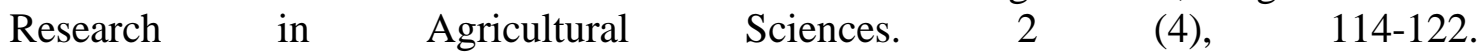
https://doi.org/10.18488/journal.68/2015.2.4/68.4.114.122

Oluwasola, O. (2015). Vegetable Production, Livelihood Diversification and Employment Generation in Oyo State, Nigeria, Journal of Agricultural Science, 7(8),165-174. https://doi.org/10.5539/jas.v7n8p165

Omotesho, O., Muhammed-Lawal, A., Abdulganiyu, A., \& Amolegbe, K. (2015). Economics of Leafy Vegetable Production among Pastoralists in Kwara State, Nigeria. International Journal of Agricultural Science, Research and Technology in Extension and Education Systems, 5(4),245-252.

Onwutuebe, C. J. (2019).Patriarchy and Women Vulnerability to Adverse Climate Change in Nigeria. SAGE Open, DOI: $\quad 10.1177 / 2158244019825914$. journals.sagepub.com/home/sgo. https://doi.org/10.1177/2158244019825914

Oseni, G., Paul, C., Markus, G, \& Paul, W. (2015). Explaining gender differentials in agricultural production in Nigeria. Agricultural Economics, 46(3), 285-310. https://doi.org/10.1111/agec.12166

Oyakhilomen, O. (2013). Gender Influence on the Income of Maize Farmers in Giwa Local Government Area of Kaduna State, Russian Journal of Agricultural and SocioEconomic Sciences, 1(25), 14-18. https://doi.org/10.18551/rjoas.2014-01.03

Rufai, A.M., Salman, K.K., \& Salawu, M.B. (2018). Input Utilization and Agricultural Labor Productivity: A Gender Analysis, Building a Resilient and Sustainable Agriculture in Sub-Saharan Africa, 55-79. https://link.springer.com/chapter/10.1007/978-3-31976222-7_4 Springer Link. https://doi.org/10.1007/978-3-319-76222-7_4

Sumane, S., Kunda, I., Knickel K., Strauss A., Tisenkopfs T. Rios I., Rivera M., Chebach T., \& Ashkenazy, A., et. al. (2017). Local and farmers' knowledge matters! How integrating informal and formal knowledge enhances sustainable and resilient $\begin{array}{lllll}\text { agriculture.Journal of } & \text { Rural } & \text { Studies, } & \text { xxx, } & 1-10 \text {. }\end{array}$ https://doi.org/10.1016/j.jrurstud.2017.01.020

Villarreal, M. (2013). Decreasing Gender Inequality in Agriculture: Key to Eradicating Hunger. The Brown Journal of World Affairs, 20(1), 169-177. Retrieved September 24, 2020, from http://www.jstor.org/stable/24590892 
Olanrewaju, K.O., Akintunde, O.K., Adeoye, I.B. and Bamiwuye, O.A.

\section{APPENDICES}

Table 1. Gender distribution of socio-ecomnomic characteristics of leafy vegetable farmers

\begin{tabular}{lll}
\hline $\begin{array}{l}\text { Socio-economic characteristics } \\
\text { Age }\end{array}$ & Male $(\boldsymbol{\%})$ & Female $(\boldsymbol{\%})$ \\
$\quad 30$ years & 33.3 & 21.4 \\
31-45 years & 35.9 & 71.5 \\
Above 45 years & 30.8 & 7.1 \\
Level of education & & \\
None & 19.2 & 28.6 \\
Primary & 30.8 & 40.5 \\
Secondary & 32.1 & 31.0 \\
Tertiary & 18.0 & 0.0 \\
Farming experience & & \\
10years and below & 43.6 & 64.3 \\
11-20 years & 42.3 & 23.8 \\
21-30 years & 11.5 & 11.9 \\
Above 30years & 2.6 & 0 \\
Mode of land acquisition & & \\
Inheritance & 25.6 & 21.4 \\
Rent & 48.7 & 52.4 \\
Bought & 2.6 & 9.5 \\
Others & 23.1 & 16.7 \\
\hline Source: Field Survey Data, 2019. & & \\
\hline
\end{tabular}

Source: Field Survey Data, 2019. 
Table 2: Distribution of leafy vegetable farmers according to their production activities

\begin{tabular}{|c|c|c|}
\hline & Male $(\%)$ & Female \\
\hline \multicolumn{3}{|l|}{ Leafy vegetables grown } \\
\hline Amaranthus & 34.6 & 33.3 \\
\hline Ewedu & 38.5 & 33.3 \\
\hline Soko & 7.6 & 19.1 \\
\hline Igbagba & 19.2 & 14.2 \\
\hline \multicolumn{3}{|l|}{ Production knowledge } \\
\hline Personal experience & 64.1 & 66.7 \\
\hline Sourced from co-farmers & 20.5 & 23.8 \\
\hline Extension agents & 15.4 & 0.5 \\
\hline \multicolumn{3}{|c|}{ Contact with extension agents } \\
\hline No & 65.4 & 52.4 \\
\hline Yes & 34.6 & 47.6 \\
\hline \multicolumn{3}{|c|}{ Source of credit for production } \\
\hline Cooperatives & 9.0 & 7.1 \\
\hline Savings & 66.7 & 73.8 \\
\hline Both & 15.4 & 16.7 \\
\hline Others & 9.0 & 2.4 \\
\hline \multicolumn{3}{|c|}{ Enterprise decision making } \\
\hline Male task & 68.0 & 33.3 \\
\hline Female task & 6.4 & 50.0 \\
\hline Joint task & 25.6 & 16.7 \\
\hline \multicolumn{3}{|c|}{ Source of seed for planting } \\
\hline Shops & 43.6 & 33.3 \\
\hline revious planting & 9.0 & 4.8 \\
\hline Both & 47.4 & 61.9 \\
\hline
\end{tabular}

Source: Field survey data, 2019.

\section{Table 3: Distribution of labour utilization for production activities by gender}

\begin{tabular}{lll} 
Labour & Mean number of production activities \\
\hline & Male farmers & Female farmers \\
Personally done & $11.5 \pm 3.01$ & $9.26 \pm 4.02$ \\
Spouse & $4.38 \pm 4.12$ & $5.31 \pm 4.90$ \\
Delegated to girl child & $2.23 \pm 2.33$ & $3.42 \pm 2.53$ \\
Delegated to male child & $2.87 \pm 2.6$ & $3.5 \pm 2.61$ \\
Hired labour & $2.0 \pm 1.65$ & $3.11 \pm 1.31$ \\
\hline
\end{tabular}

Source: Field survey, 2019 
Journal of Agriculture and Food Sciences Volume 19 Number 1, April 2021 pp 120-133
Olanrewaju, K.O., Akintunde, O.K., Adeoye, I.B. and Bamiwuye, O.A.

Table 4: Estimates of paired t- test statistics for gender differential in family labour utilization

\begin{tabular}{|c|c|c|c|c|c|c|c|c|}
\hline \multirow[t]{3}{*}{ Sex } & & \multirow{3}{*}{$\begin{array}{l}\text { Mean } \\
\text { difference }\end{array}$} & \multirow{3}{*}{$\begin{array}{l}\text { Std. } \\
\text { Error } \\
\text { Mean }\end{array}$} & \multicolumn{3}{|c|}{ 95\% Confidence } & \multirow{3}{*}{ df } & \multirow{3}{*}{ Sig. } \\
\hline & & & & Interval & & $\mathrm{t}$ & & \\
\hline & & & & Lower & Upper & & & \\
\hline \multirow{4}{*}{$\begin{array}{l}\text { Male } \\
\text { farmers }\end{array}$} & Boy task & 0.6410 & 0.1365 & 0.3692 & 0.9129 & \multirow[t]{2}{*}{4.70} & \multirow{2}{*}{7} & \multirow[t]{2}{*}{$0.000 *$} \\
\hline & Girl task & & & & & & & \\
\hline & Personally & \multirow[t]{2}{*}{7.1154} & \multirow[t]{2}{*}{0.6954} & \multirow[t]{2}{*}{5.7308} & \multirow[t]{2}{*}{8.5000} & 10.23 & \multirow{2}{*}{7} & $0.000 *$ \\
\hline & Wife & & & & & & & \\
\hline \multirow{3}{*}{$\begin{array}{l}\text { Female } \\
\text { farmers }\end{array}$} & Boy task & 0.0952 & 0.1067 & 0.1203 & 0.3108 & 0.89 & \multirow{2}{*}{1} & 0.377 \\
\hline & Girl ask & & & & & & & \\
\hline & $\begin{array}{l}\text { Personally } \\
\text { Husband }\end{array}$ & 3.9523 & 1.2927 & 1.3416 & 6.5632 & 3.06 & 1 & $0.004 *$ \\
\hline
\end{tabular}

Source: Field survey, 2019.

*Significant at P $₫ 0.05$

Table 5: Gender disaggregated results of leafy vegetable production income

$\begin{array}{lll}\text { Income } & \text { Males (\%) } & \text { Females (\%) }\end{array}$

\begin{tabular}{|c|c|c|}
\hline$\leq \notin 30,000$ & 46.2 & 35.7 \\
\hline$¥ 30,001-\approx 40,000$ & 25.6 & 30.9 \\
\hline$¥ 40,001-丹 50,000$ & 17.9 & 16.7 \\
\hline Above $\$ 50,000$ & 10.3 & 16.7 \\
\hline $\operatorname{Mean}(\mathrm{N}) \pm \mathrm{sd}$ & $45,076.92 \pm 8745.61$ & $39,880.95 \pm 5321.28$ \\
\hline
\end{tabular}

Source: Field survey, 2019.

Table 6: Estimates of t-test statistics for gender differential in income and labour utilization

\begin{tabular}{|c|c|c|c|c|c|c|c|}
\hline & Sex & Mean & $\begin{array}{c}\text { Std. } \\
\text { Deviation }\end{array}$ & $\begin{array}{l}\text { M } \\
\text { ean } \\
\text { diff. }\end{array}$ & $\mathrm{t}$ & df & Sig. \\
\hline \multirow[t]{2}{*}{ Income } & Male & 45076.92 & 87745.614 & 5195.97 & 0.38 & 118 & 0.70 \\
\hline & Female & 39880.95 & 15321.279 & & & & \\
\hline \multirow[t]{2}{*}{ Labour } & Male & 2.0000 & 1.65145 & -1.11 & -3.79 & 118 & $0.00 *$ \\
\hline & Female & 3.1190 & 1.31042 & & & & \\
\hline
\end{tabular}

Source: Field survey, 2019. *Significant at P $₫ 0.001$ 